\title{
Synthesis of Enantiomerically Pure trans-3,4-Substituted Cyclopentanols by Enzymatic Resolution
}

\author{
Åsa Rosenquist, Ingemar Kvarnström, Stefan C. T. Svensson, Björn Classon ${ }^{\mathrm{b}}$ and Bertil \\ Samuelsson ${ }^{\mathrm{b}, *, \dagger}$
}

${ }^{a}$ Department of Chemistry, Linköping University, S-581 83 Linköping, Sweden and ${ }^{\mathrm{b}}$ Department of Organic Chemistry, Arrhenius Laboratory, Stockholm University, S-106 91 Stockholm, Sweden

\begin{abstract}
Rosenquist, Å., Kvarnström, I. and Svensson, S. C. T., 1992. Synthesis of Enantiomerically Pure trans-3,4-Substituted Cyclopentanols by Enzymatic Resolution. Acta Chem. Scand. 46: 1127-1129.
\end{abstract}

Over the last two decades much attention has been focussed on the development of methods for the construction of chiral derivatives of cyclopentane. This structural element is a common feature in a wide array of natural products, including the medically important prostaglandins ${ }^{1}$ and brefeldins. ${ }^{2.3}$ The discovery of naturally occurring antiviral adenosine analogues (-)-aristeromycin ${ }^{4}$ and (-)-neplano$\mathrm{cin}^{5}$ has recently generated much synthetic interest in carbocyclic nucleoside analogues. ${ }^{6}$

For an on-going project in our laboratory we required both enantiomers (-)-1 and (+)-1 of trans-3,4-bis(benzoyloxymethyl)cyclopentanol. To prepare these structures we used an enantioselective enzymatic hydrolysis of trans-3,4bis(methoxycarbonyl)cyclopentanone $( \pm)-4$, a reaction for which there is little literature precedence ${ }^{7}$ (Scheme 1$)$.

\section{Results and discussion}

Racemic ( \pm )-4 was synthesised starting with a Diels-Alder reaction of 3-sulfolene and dimethyl fumarate, ${ }^{8}$ followed by oxidative cleavage of the double bond, cyclisation and decarboxylation. ${ }^{9}$ The total yield of $( \pm)-4$ from the starting material dimethyl fumarate was $74 \%$, which is twice that reported previously. ${ }^{10}$

Resolution of ( \pm )-4 by hydrolysis using pig liver esterase (PLE) as a catalyst has been examined by Suemene et $\mathrm{al}^{7}$ They obtained both enantiomers of $( \pm)-4$ with $>95 \%$ ee, in phosphate buffer containing $5 \%$ acetone. Optically pure $(3 R, 4 R)-4$, having $[\alpha]_{\mathrm{D}}-133.3^{\circ}$, was obtained in a yield of $40 \%$ after ca. $60 \%$ conversion. Several attempts to reproduce this result were unsuccessful. The highest optical purity we obtained was $82 \%$ ee. Better results were, however, obtained when acetone was excluded from the reaction medium. The diester ( \pm )-4 was thus hydrolysed with PLE

\footnotetext{
* To whom correspondence should be addressed.

Address also: Astra Hässle AB, S-431 83 Mölndal, Sweden.
}

in aqueous phosphate buffer at $\mathrm{pH} 7$ and stopped at $40 \%$ conversion, to yield (+)-4 with an ee of $91 \%$ in $40 \%$ yield. In order to optimise yield and optical purity of both enantiomers the hydrolysis was stopped at near $50 \%$ conversion. Separation by column chromatography gave the semicrystalline diester $(-)-4(51 \%, 79 \%$ ee) and crystalline monoacid $(+)-5(47 \%)$. The monoacid $(+)-5$ was esterified
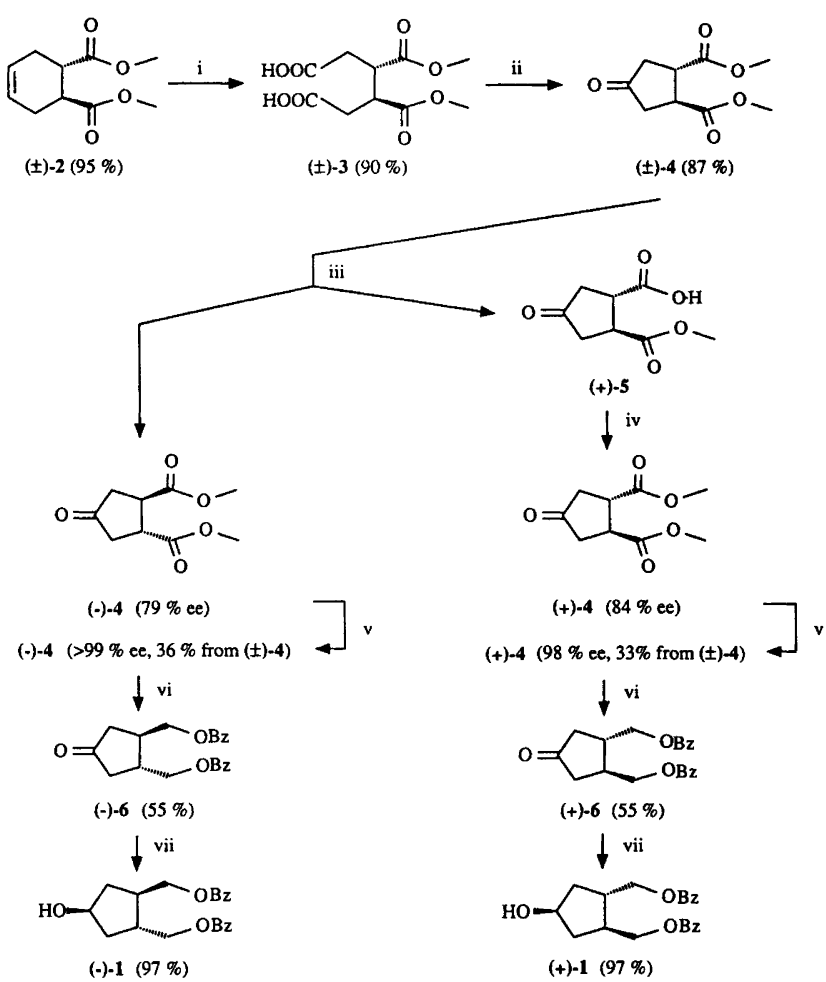

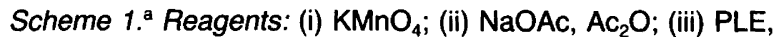
phosphate buffer $\mathrm{pH} 7$; (iv) $\mathrm{MeOH}, \mathrm{AcCl}$ (cat.); (v) crystallisation of racemate from mother liquor; (vi) a, ethylene glycol, $p-\mathrm{TsOH}$; b, $\mathrm{LiAlH}_{4}, \mathrm{Et}_{2} \mathrm{O} ; \mathrm{c}, \mathrm{BzCl}$, pyridine; d, $\mathrm{HCl}$ (aq)-MeOH; (vii) $\mathrm{NaBH}_{4}, \mathrm{MeOH}$. 
to give semicrystalline (+)-4 in $90 \%$ yield and with $84 \%$ ee. Crystallisation of the semicrystalline diesters (-)-4 and $(+)-\mathbf{4}$ gave crystals of racemic diester $( \pm)-4$ and an enantiomerically enriched mother liquor with an ee $\geq 98 \%$ for both (-)-4 and (+)-4. The total yields in the resolution step were $36 \%$ and $33 \%$ for enantiomerically pure (-)-4 and (+)-4, respectively.

The desired products $(-)-1$ and $(+)-1$ were prepared from (-)-4 and (+)-4, respectively, via ketalisation, lithium aluminium hydride reduction, benzoylation, deketalisation, followed by sodium borohydride reduction. The enantiomeric purity of these cyclopentanols was checked by analysis of their (1S)-camphanonyl esters on HPLC, ${ }^{11}$ which gave an optical purity of $>99 \%$.

\section{Experimental}

General methods. ' $\mathrm{H}$ and ${ }^{13} \mathrm{C}$ NMR spectra were recorded on a JEOL FX-100 instrument using $\mathrm{CDCl}_{3}$ or acetone- $d_{6}$ as solvents with $\mathrm{SiMe}_{4}$ as an internal standard. TLC was performed on Merck precoated $60 \mathrm{~F}_{254}$ plates. The spots were visualized by UV light and/or charring with ethanolsulphuric acid-acetic acid-p-anisaldehyde, 90:3:1:2. Column chromatography was performed using silica gel 60 (0.040-0.063 mm, Merck). Optical rotations were measured in $\mathrm{CHCl}_{3}$ solutions at room temperature using a Perkin Elmer 141 instrument. HPLC was performed on a Nucleosil $\mathrm{NH}_{2}, 4.6 \times 200 \mathrm{~mm}, 5 \mu \mathrm{m}$ silica gel column with isooctane-chloroform, $82: 18$ (flow rate $0.7 \mathrm{ml} \mathrm{min}^{-1}$ ), as the eluant (UV detection at $254 \mathrm{~nm}$ ). The PLE enzymatic hydrolyses were carried out with a pH-stat. Pig liver esterase (PLE, $130 \mathrm{U} \mathrm{mg}^{-1}$ ) was purchased from Boehringer $\mathrm{GmbH}$, Mannheim.

rac-trans-3,4-Bis(methoxycarbonyl)hexanedioic acid [( \pm$)-3]$. rac-trans-4,5-Bis(methoxycarbonyl)cyclohexene ${ }^{8}$ [( \pm$)-2](11.9 \mathrm{~g}, 60.0 \mathrm{mmol})$ in acetone $(15 \mathrm{ml})$ was slowly added to an ice-cold well-stirred mixture of potassium permanganate $(30.1 \mathrm{~g}, 190 \mathrm{mmol})$ in water $(145 \mathrm{ml})$. The temperature was maintained below $+5^{\circ} \mathrm{C}$ during the addition and was then allowed to rise to room temperature. After the mixture had been stirred for $3 \mathrm{~h}$ at room temperature sodium hydrogensulphite $(30 \mathrm{~g})$ was added and the mixture was stirred for additional $20 \mathrm{~min}$ before it was carefully acidified to $\mathrm{pH} 2$ with concentrated $\mathrm{HCl}$. The now clear solution was extracted several times with a mixture of tetrahydrofuran and ethyl acetate (1:1), dried $\left(\mathrm{MgSO}_{4}\right)$ and concentrated. Crystallisation from ethyl acetate-hexane gave (士)-3 (14.08 g, $90 \%)$, m.p. $168-169^{\circ} \mathrm{C} .{ }^{1} \mathrm{H}$ NMR $(100$ $\mathrm{MHz}$, acetone- $\left.d_{6}\right): \delta 2.4-3.2\left(4 \mathrm{H}, \mathrm{m}, 2 \mathrm{CH}_{2}\right), 3.15-3.34(2$ $\mathrm{H}, \mathrm{m}, 2 \mathrm{CH}), 3.66\left(6 \mathrm{H}, \mathrm{s}, 2 \mathrm{OCH}_{3}\right) 8.65(2 \mathrm{H}, \mathrm{s}, 2$ $\mathrm{COOH}) .{ }^{13} \mathrm{C} \mathrm{NMR}\left(25.05 \mathrm{MHz}\right.$, acetone- $\left.d_{6}\right): \delta 32.9(2$ $\left.\mathrm{CH}_{2}\right), 42.5(2 \mathrm{CH}), 51.7\left(2 \mathrm{OCH}_{3}\right), 172.1$ and 172.4 $(\mathrm{C}=\mathrm{O})$. Anal. $\mathrm{C}_{10} \mathrm{H}_{14} \mathrm{O}_{8}: \mathrm{C}, \mathrm{H}$.

rac-trans-3,4-Bis(methoxycarbonyl)cyclopentanone [( \pm )-4]. A mixture of $( \pm)-3(9.40 \mathrm{~g}, 35.9 \mathrm{mmol})$ and acetic an- hydride $(44 \mathrm{ml})$ was vigourously stirred for $1 \mathrm{~h}$ at $130^{\circ} \mathrm{C}$. The mixture was cooled, anhydrous sodium acetate $(2.4 \mathrm{~g})$ was added and heating was resumed at $130^{\circ} \mathrm{C}$ until evolution of $\mathrm{CO}_{2}$ had ceased (20 min). Excess of acetic anhydride was destroyed by adding methanol $(26 \mathrm{ml})$ during cooling in an ice-bath. The reaction mixture was neutralised with sodium hydrogen carbonate $(2.8 \mathrm{~g})$, diluted with water $(100 \mathrm{ml})$ and extracted twice with dichloromethane. The combined organic layers were dried $\left(\mathrm{MgSO}_{4}\right)$, concentrated and purified by flash chromatography on silica gel (toluene-EtOAc, gradient elution 10:1 to 4:1). The product was crystallised from diethyl ether-hexane to give the diester ( \pm )-4 (6.27 g, 87\%), m.p. 64-65 ${ }^{\circ} \mathrm{C}$. ${ }^{1} \mathrm{H}$ NMR $(100$ $\left.\mathrm{MHz}, \mathrm{CDCl}_{3}\right): \delta 2.52-2.65\left(4 \mathrm{H}, \mathrm{m}, 2 \mathrm{CH}_{2}\right), 3.31-3.47(2$ $\mathrm{H}, \mathrm{m}, 2 \mathrm{CH}), 3.76\left(6 \mathrm{H}, \mathrm{s}, 2 \mathrm{OCH}_{3}\right){ }^{13} \mathrm{C} \mathrm{NMR}(25.05 \mathrm{MHz}$, $\left.\mathrm{CDCl}_{3}\right): \delta 40.8\left(2 \mathrm{CH}_{2}\right), 43.5(2 \mathrm{CH}), 52.4\left(2 \mathrm{OCH}_{3}\right), 172.8$ and $211.8(\mathrm{C}=\mathrm{O})$.

trans-(3R,4R)-Bis(methoxycarbonyl)cyclopentanone [(-)-4]. PLE (pig liver esterase, $600 \mu \mathrm{l}, 10 \mathrm{mg} \mathrm{m}^{-1}$ ) was added to a stirred solution of the racemic diester $( \pm)-4(4.50 \mathrm{~g}, 22.5$ $\mathrm{mmol}$ ) and $10 \mathrm{mM}$ phosphate buffer solution $(\mathrm{pH} \mathrm{7.0,} 340$ $\mathrm{ml}$ ) at room temperature. Addition of $1.0 \mathrm{M}$ aqueous $\mathrm{NaOH}$ to maintain $\mathrm{pH} 7.0$ was continued until 0.48 equivalents $(10.8 \mathrm{ml})$ of base had been consumed. Hydrolysis was stopped by careful acidification of the reaction suspension to $\mathrm{pH} 3$ with aqueous $\mathrm{HCl}(1 \mathrm{M}, 10 \mathrm{ml})$. The mixture was extracted several times with ethyl acetate and the combined organic layers were dried $\left(\mathrm{MgSO}_{4}\right)$ and concentrated, and the residue was purified by flash column chromatography on silica gel (EtOAc-hexane 2:1) to give the diester $(-)-4(2.30 \mathrm{~g}, 51 \%)$, with an $[\alpha]_{\mathrm{D}}$ of $-105.2^{\circ}, 79 \%$ ee, as a semicrystalline syrup. Further elution (EtOAchexane-AcOH, 10:5:1) gave the monoacid (+)-5 (1.98 g, $47 \%$ ), as a white solid. Crystallisation of the semicrystalline (-)-4 from diethyl ether-hexane gave crystals of the racemic diether $( \pm)-4$ and a mother liquor, which after concentration gave an enantiomerically pure liquid diester (-)-4 (1.60 g, 36\%), $[\alpha]_{\mathrm{D}}-133.4^{\circ}$ (c 0.96, chloroform) (lit. ${ }^{7}[\alpha]_{D}-133 \cdot 3^{\circ}$ ). Anal. $\mathrm{C}_{9} \mathrm{H}_{12} \mathrm{O}_{5}: \mathrm{C}, \mathrm{H}$.

Compound (+)-5 had m.p. $84-85^{\circ} \mathrm{C}$. ${ }^{1} \mathrm{H}$ NMR $(100$ $\left.\mathrm{MHz}, \mathrm{CDCl}_{3}\right): \delta 2.36-2.88\left(4 \mathrm{H}, \mathrm{m}, 2 \mathrm{CH}_{2}\right), 3.26-3.59(2$ $\mathrm{H}, \mathrm{m}, 2 \mathrm{CH}), 3.76\left(3 \mathrm{H}, \mathrm{s}, \mathrm{OCH}_{3}\right), 9.88(1 \mathrm{H}, \mathrm{s}, \mathrm{COOH})$. ${ }^{13} \mathrm{C}$ NMR $\left(25.05 \mathrm{MHz}, \mathrm{CDCl}_{3}\right): \delta 41.7(\mathrm{CH}), 41.8(\mathrm{CH})$, $43.3\left(2 \mathrm{CH}_{2}\right), 52.6\left(\mathrm{OCH}_{3}\right), 172.8,177.8$ and $212.2(\mathrm{C}=\mathrm{O})$.

trans-(3S,4S)-Bis(methoxycarbonyl)cyclopentanone [(+)-4]. Acetyl chloride $(2 \mathrm{ml})$ was added to a cold stirred solution of $(+)-4(1.98 \mathrm{~g})$ in methanol $(40 \mathrm{ml})$. The mixture was stirred for $17 \mathrm{~h}$ at room temperature. The solvent was evaporated and the residue was purified by column chromatography on silica gel (toluene-EtOAc 3:1) to give the diester (+)-4 as a semicrystalline syrup (1.92 g), with an $[\alpha]_{\mathrm{D}}+112^{\circ}, 84 \%$ ee. Crystallisation from diethyl etherhexane gave white crystals of racemic diester ( \pm )-4 and a mother liquor, which after concentration gave a $98 \%$ enantiomerically pure liquid diester $(+)-4(1.48 \mathrm{~g}$, total yield 
from rac-material $33 \%$, $[\alpha]_{\mathrm{D}}+130.1^{\circ}$ (c 0.98 , chloroform). Anal. $\mathrm{C}_{9} \mathrm{H}_{12} \mathrm{O}_{5}$ : $\mathrm{C}, \mathrm{H}$.

trans-(3R,4R)-Bis(benzoyloxymethyl)cyclopentanone [(-)-6]. A mixture of (-)-4 (0.93 g, $4.6 \mathrm{mmol})$, ethylene glycol $(6.5$ $\mathrm{ml}, 0.12 \mathrm{~mol})$ and $p$-toluenesulphonic acid monohydrate $(25 \mathrm{mg})$ in toluene $(50 \mathrm{ml})$ was refluxed for $6 \mathrm{~h}$ with a Dean-Stark trap. Sodium hydrogen carbonate $(20 \mathrm{mg})$ was added and after being stirred for $5 \mathrm{~min}$ the mixture was washed with saturated aqueous sodium hydrogen carbonate, dried $\left(\mathrm{MgSO}_{4}\right)$ and concentrated to give a crude ketal diester. According to ${ }^{1} \mathrm{H}$ NMR spectroscopy, the product was free from unchanged ketone. The crude ketal diester in dry diethyl ether $(15 \mathrm{ml})$ was added dropwise over $1 \mathrm{~h}$ to an ice-cold mixture of lithium aluminium hydride $(0.35 \mathrm{~g}, 9.2$ mmol) in dry diethyl ether $(35 \mathrm{ml})$. The mixture was stirred at room temperature for $3 \mathrm{~h}$ before the excess of lithium aluminium hydride was decomposed by successive addition of water $(0.5 \mathrm{ml}), 3 \mathrm{M}$ aqueous $\mathrm{NaOH}(0.5 \mathrm{ml})$ and water $(1.5 \mathrm{ml})$. After a further hour of stirring $\mathrm{MgSO}_{4}(20 \mathrm{~g})$ was added and the stirring was prolonged for $5 \mathrm{~min}$. The precipitate and $\mathrm{MgSO}_{4}$ were removed by filtration and washed several times with ethyl acetate. The filtrate was concentrated to give a crude oil of the diol. Benzoyl chloride (2.3 $\mathrm{ml}, 20.1 \mathrm{mmol}$ ) was added dropwise to a stirred solution of the diol in pyridine $(13.5 \mathrm{ml})$. The mixture was stirred for 3 $h$ at room temperature. Water $(5 \mathrm{ml})$ was added, and after being stirred for $10 \mathrm{~min}$, the mixture was diluted with saturated aqueous sodium hydrogen carbonate and dichloromethane. The organic layer was separated and washed with saturated sodium hydrogen carbonate, dried $\left(\mathrm{MgSO}_{4}\right)$ and concentrated. Column chromatography (tolueneEtOAc 3:1) on a short column of silica gel gave a syrupy residue containing the dibenzoylated ketal and traces of the dibenzoylated ketone (-)-6. The syrup was dissolved in methanol $(92 \mathrm{ml})$ and $2 \mathrm{M}$ aqueous $\mathrm{HCl}(31 \mathrm{ml})$, stirred at room temperature for $2 \mathrm{~h}$ and then at $50^{\circ} \mathrm{C}$ for additional 2 $h$. The solution was neutralised with sodium hydrogen carbonate $(5.2 \mathrm{~g})$, diluted with water and extracted with dichloromethane. The organic layer was dried $\left(\mathrm{MgSO}_{4}\right)$, concentrated and crystallised from diethyl ether-hexane to give the product (-)-6 as needles $[0.90 \mathrm{~g}, 55 \%$ from (-)-4], m.p. $85-86^{\circ} \mathrm{C},[\alpha]_{\mathrm{D}}-59.1^{\circ}$ (c 1.04, chloroform). ${ }^{1} \mathrm{H}$ NMR (100 MHz, $\left.\mathrm{CDCl}_{3}\right): \delta$ 2.12-2.73 (6 H, m, $2 \mathrm{CH}, 2$ $\left.\mathrm{CH}_{2}\right), 4.50\left(4 \mathrm{H}, \mathrm{d}, 2 \mathrm{CH}_{2}-\mathrm{OBz}\right), 7.36-7.64$ and 7.94-8.07 $(10 \mathrm{H}, \mathrm{m}$, aromatic $\mathrm{H}) .{ }^{13} \mathrm{C}$ NMR $\left(25.05 \mathrm{MHz}, \mathrm{CDCl}_{3}\right): \delta$ $38.3\left(2 \mathrm{CH}_{2}\right), 41.6(2 \mathrm{CH}), 65.9\left(2 \mathrm{CH}_{2}-\mathrm{OBz}\right), 128.2,129.2$ and 133.0 (aromatic $\mathrm{C}$ ), 165.9 and $214.9(\mathrm{C}=\mathrm{O})$. Anal. $\mathrm{C}_{21} \mathrm{H}_{20} \mathrm{O}_{5}: \mathrm{C}, \mathrm{H}$.

trans-(3S,4S)-Bis(benzoyloxymethyl)cyclopentanone [(+)-6]. Compound $(+)-4$ was converted into $(+)-6$, m.p. $85-86^{\circ} \mathrm{C}$,
$[\alpha]_{D}+58.9^{\circ}$ (c 0.84 , chloroform), as described above for $(-)-6$, in a comparable yield. Anal. $\mathrm{C}_{21} \mathrm{H}_{20} \mathrm{O}_{5}: \mathrm{C}, \mathrm{H}$.

trans-(3R,4R)-Bis(benzoyloxymethyl)cyclopentanol [(-)-1]. Sodium borohydride (41 $\mathrm{mg}, 1.10 \mathrm{mmol}$ ) was added in successive portions to compound (-)-6 (193 mg, 0.55 $\mathrm{mmol})$ in methanol $(10 \mathrm{ml})$. The mixture was stirred at room temperature for $30 \mathrm{~min}$, and then diluted with water and diethyl ether. The organic layer was washed with saturated aqueous sodium chloride, dried $\left(\mathrm{MgSO}_{4}\right)$ and concentrated to a syrup which was purified by column chromatography on silica gel (toluene-EtOAc 1:1) to yield pure (-)-1 (189 mg, $97 \%),[\alpha]_{D}-16.4^{\circ}$ (c 1.09, chloroform). ${ }^{1} \mathrm{H}$ NMR (100 MHz, $\left.\mathrm{CDCl}_{3}\right): \delta 1.6-2.7\left(7 \mathrm{H}, \mathrm{m}, 2 \mathrm{CH}, 2 \mathrm{CH}_{2}\right.$, $\mathrm{OH}), 4.41$ (4 H, t, $\left.2 \mathrm{CH}_{2}-\mathrm{OBz}\right), 7.34-7.56$ and 7.97-8.09 $(10 \mathrm{H}, \mathrm{m}$, aromatic $\mathrm{H}) .{ }^{13} \mathrm{C}$ NMR $\left(25.05 \mathrm{MHz}, \mathrm{CDCl}_{3}\right): \delta$ $38.3,39.3,39.8,40.0\left(2 \mathrm{CH}_{2}, 2 \mathrm{CH}\right), 67.4,68.2\left(2 \mathrm{CH}_{2}-\right.$ $\mathrm{OBz}$ ), 72.5 (CHOH), 128.1, 129.3, 129.8, 132.8 (aromatic C), $166.3(\mathrm{C}=\mathrm{O})$. Anal. $\mathrm{C}_{21} \mathrm{H}_{22} \mathrm{O}_{5}: \mathrm{C}, \mathrm{H}$.

trans-(3S,4S)-Bis(benzoyloxymethyl)cyclopentanol $[(+)-1]$. Compound $(+)-6$ was reduced with sodium borohydride, as described for $(-)-6$, to give $(+)-1$ in a comparable yield, $[\alpha]_{D}+16.4^{\circ}$ (c 1.00, chloroform). Anal. $\mathrm{C}_{21} \mathrm{H}_{22} \mathrm{O}_{5}: \mathrm{C}, \mathrm{H}$.

Acknowledgements. We thank the Swedish National Board of Industrial and Technical Development and Medivir AB for financial support.

\section{References}

1. Roberts, S. M. and Schienmann, F. New Synthetic Routes to Prostaglandins and Thromboxanes, Academic Press, London 1982.

2. Kitahara, T. and Mori, K. Tetrahedron 40 (1985) 2935.

3. Hatakeyama, S., Sugawara, K., Kavamura, M. and Takono, S. Synlett (1990) 691.

4. Kishi, T., Murio, M., Kusaka, T., Nishikawa, M., Kamiya, K. and Mizuno, K. Chem. Pharm. Bull. 20 (1972) 940.

5. Hayashi, M., Yaginuma, S., Yoshioka, H. and Nakatsy, K. J. Antibiot. 34 (1981) 675.

6. (a) Marques, V. E. and Lim, M.-I. Med. Res. Rev. 6 (1986) 1; (b) Wolfe, S. M., Andersson, B. L., Borcherding, D. R. and Borchardt, R. T. J. Org. Chem. 55 (1990) 4712.

7. Suemune, H., Tanaka, M., Obaishi, H. and Sakai, K. Chem. Pharm. Bull. 36 (1988) 15.

8. Sample, T. E. and Hatch, L. F. Org. Synth., Coll. Vol. VI (1988) 454.

9. Gais, H., Bülow, G., Zatorski, A., Jentsch, M., Maidonis, P. and Hemmerle, H. J. Org. Chem. 54 (1989) 5115.

10. (a) Dolby, L. J., Esfandiari, S., Elliger, C. A. and Marshall, K. S. J. Org. Chem. 36 (1971) 1277; (b) Kitahara, 'T., Mori, M. and Matsui, M. Tetrahedron Lett. 20 (1979) 3021.

11. Billington, D. C., Baker, R., Kulagowski, J. J. and Mawer, I. M. J. Chem. Soc., Chem. Commun. (1987) 314.

Received March 5, 1992. 